\title{
ANALYSIS OF HYDRATED CEMENTS USING A SCANNING ELECTRON MICROSCOPE-ENERGY DISPERSIVE X-RAY SPECTROMETER COMBINATION
}

DECEMBER I97| - NUMBER 21

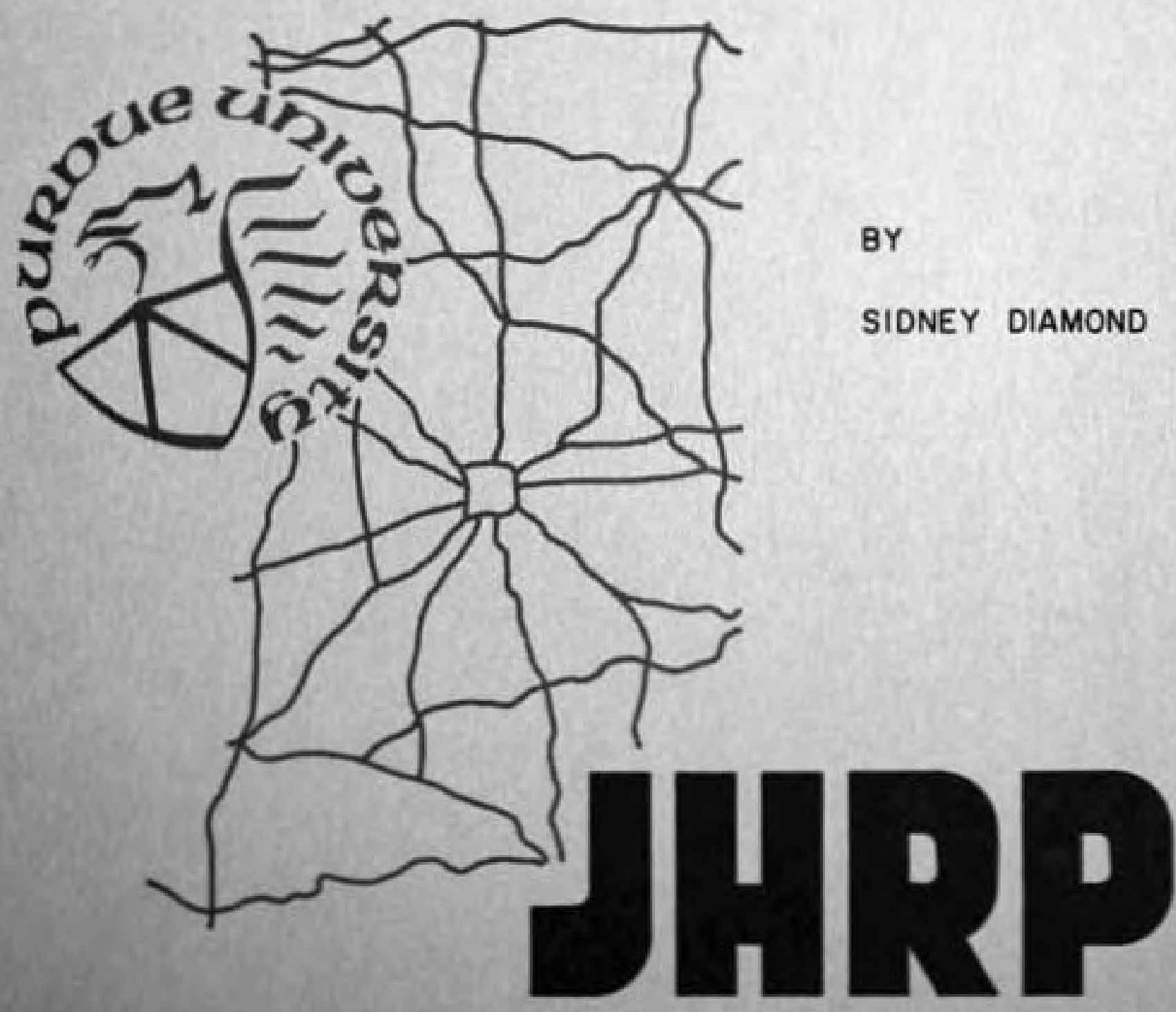
JOINT HIGHWAY RESEARCH PRONECT PUAOUE UNVERSTTY AND 
Technical Paper

ANALYSIS OF HYDRATED CEMENTS USING A SCANNING ELECTRON MICROSCOPE - ENERGY DISPERSIVE X-RAY SPECTROMETER COMBINATION

by

\author{
Sidney Diamond \\ Research Associate
}

Joint Highway Research Project

File: 5-14-5

Project: C-36-61E

Prepared as Part of an Investigation

Conducted by

Joint Highway Research Project

Engineering Experiment Station

Purdue University

In cooperation with the

Indiana State Highway Commission

and the

U.S. Department of Transportation

Federal Highway Administration

The opinions, findings and conclusions expressed in this publication are those of the authors and not necessarily those of the Federal Highway Administration. 


\section{Technical Paper}

ANALYSIS OF HYDRATED CEMENTS USING A SCANNING ELECTRON MICROSCOPE - ENERGY DISPERSIVE X-RAY SPECTROMETER

\section{COMBINATION}

To: J. F. MeLaughlin, Director

Joint Highway Research Project

FROM: H. L. Michael, Associate Director Joint Highway Research Project

December 28, 1971

Project: C-36-61E

File: $5-14-5$

The attached Technical Paper "Analysis of Hydrated Cements Using a Scanning Electron Microscope - Energy Dispersive X-Ray Spectrometer Combination"has been authored by Dr. Sidney Diamond of our staff. The paper is from research performed under the HPR Part II project titled "Fundamental Studies of Portland Cement Concrete".

The paper was presented in May 1971 at a Meeting of the American Ceramic Society and permission of all sponsors to nake the presentation was obtained on the basis of an abstract. The paper is now subnitted in its entirety for approval of publication in Cement and Concrete Research.

The paper will also be subnitted for review, conment and approval of publication to the ISHC and the FHWA.

Respectfully subnitted,

HLM:ns

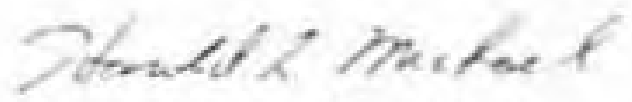

Harold L. Michael

Associate Director

cc: W. L. Dolch

W. H. Goetz

R. H. Harre11

M. L. Hayes

W. L. Grecco

M. J. Gutzwiller

R. D. Miles

J. W. Miller

C. F. Scholer

M. E. Harr

M. B. $S \cot t$

W. T. Spencer

J. A. Spooner

N. W. Steinkamp

H. R. J. Walsh

K. B. Woods

E. J. Yoder 


\section{Digitized by the Internet Archive}

in 2011 with funding from

LYRASIS members and Sloan Foundation; Indiana Department of Transportation 


\author{
ANALYSTS OF HYDRATHD CEMENTS USING A SCABSTSG ELETPON \\ MICROSCOIF, - ENERGY DISPERSTVE X-RAY SPECTRONETFR COYBT:ATIOS \\ by Sidney Dianond \\ Sehool of Civil Engineering \\ Turdue Universfty, Lafayette. Indiana 47907, t. S. A.
}

Prelininary studies of the chemical composition of individual particles and other local mferostructural units in hydrated Portland cesent pastes vere carried out using a scanning electron microscope-energv dispersive $x$-ray spectrometer combination. Calfbration curves were prepared in terms of pross peak helghts for calcfum as compared with st11con, sulfur. and aluninum Ka peaks, for a series of pure homogeneous cement and hydrated cement compoundn used as standards. The count rat to was in each case found to be 1 fnearly related to the composftional (mole) ratio. The analysis of small (approximately I's $\mathrm{im}$ diameter) areas of fracture surface of spectmens observed in the SEM was carried out for hydrated cement pastes of various apes. It was confirmed that sulfur is universally distributed throughout calcium silfcate hydrate sel regions. Local calefum to silica ratios of the gel ranged genera11y between 2 and 3 , constderablv hieher than had been expected. A number of morphological features found in hydrated cenent nastes were interpreted in the light of the chemical compositions determined. 


\section{Introduction}

This paper is the result of an investigation into the feasibility of employing a scanning electron microscope-energy dispersive $x$-ray snectrometer combination to determine the approximate composition of particles and areas of interest in hydrated cements as revealed by the scanning electron microscope (SEM). Recent SFM studies of hydrated cenent pastes and related materials suggest that the microstructure of these important substances is far more complex than had been previously appreciated. Proper interpretation and understanding of the microstructural features requires that the approximate composition or at least the chemical nature of the particles and other microstructural units be known.

Commercially avallable energy-dispersive spectrometers are now made to f1t most SEM models. They are particularly adapted to the present purpose because they do not require flat specfmen surfaces, and function well on the rough fracture surfaces usually examined in studies of hydrated cements. Rapid progress is being: made in the capabilities of these units, and more refined and much more conventent analyses than reported here should be possthle in the near future.

\section{Instrumentation}

Recent discussions of the theory and mode of operation of energydispersive $x$-ray spectrometrers have heen piven by Russ (1). Frankel and Aitken (2) and Sutfin and Ogllvie (3), among others, and the proceedings of a recent symposium on the subject are now available (4). A diagram of such a spectrometer is given as Figure 1.

Brfeflv, the device functions to detect, count, and allocate to energy classes the $x$-rays produced from a small, local recton of the specimen selected for analysis. When used in confunction with the SFM the detector takes the form of a cryogenic senfconductor 


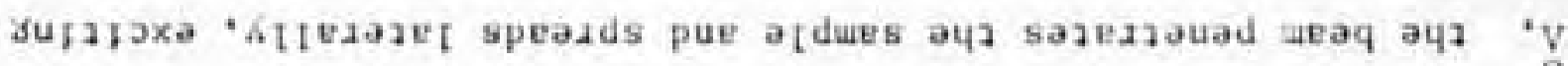

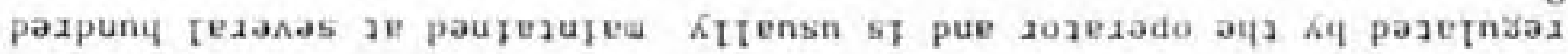

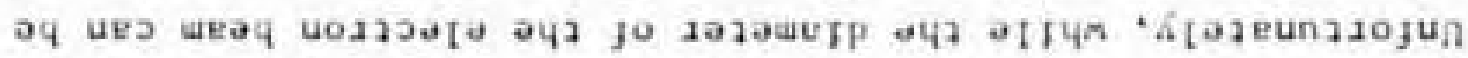

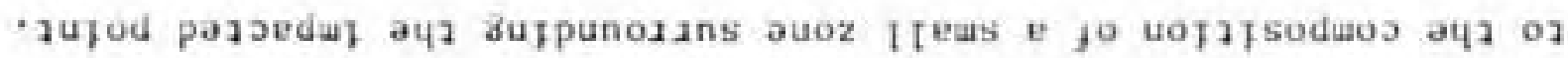

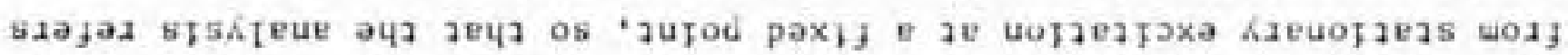

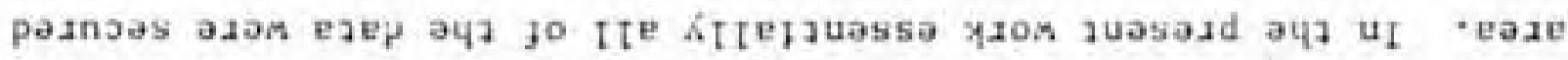

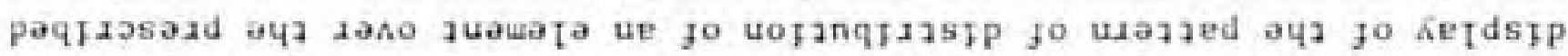

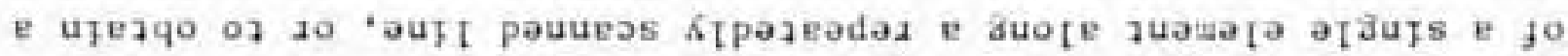

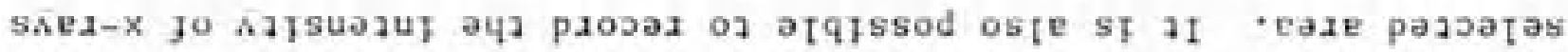

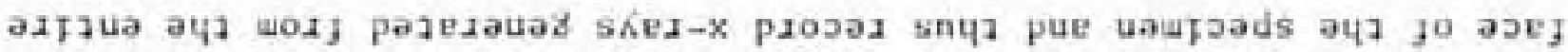

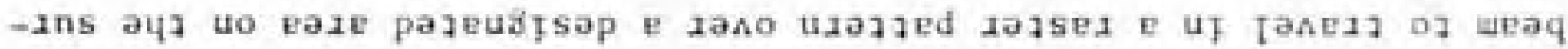

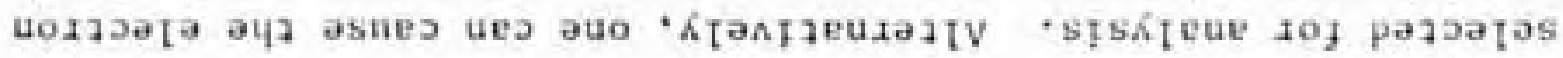

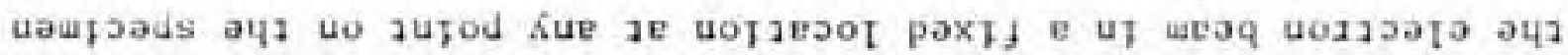

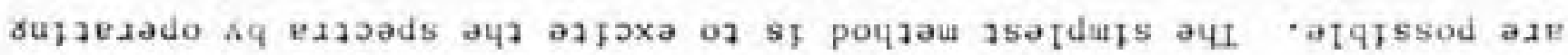

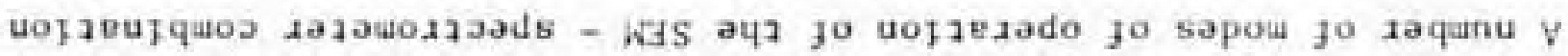

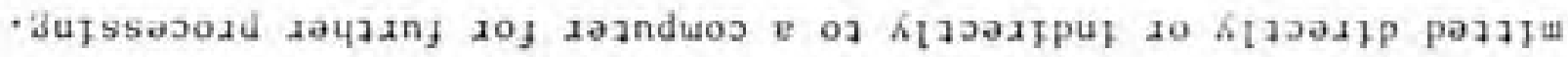

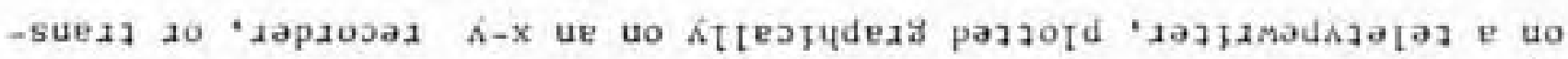

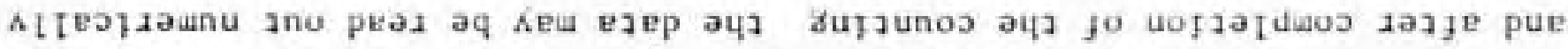

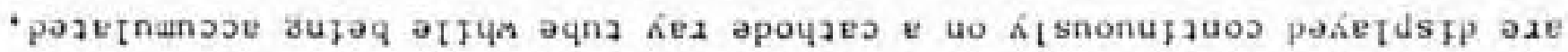

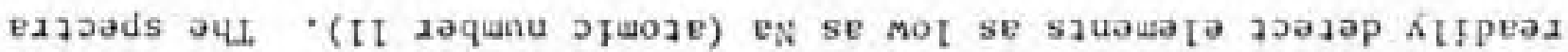

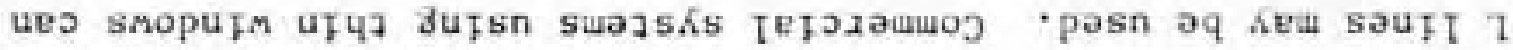

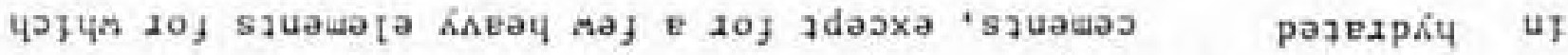

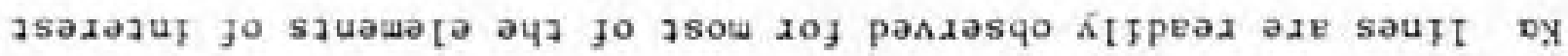

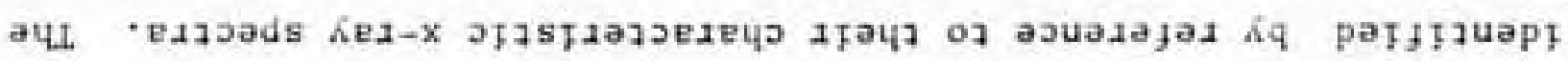

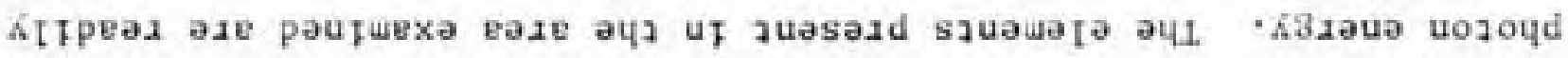

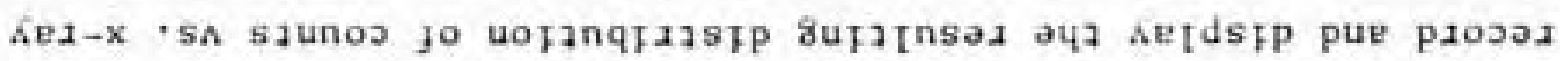
o] papfnodd st juaudjnbs "tauuey y

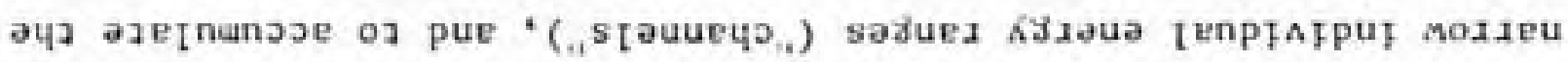

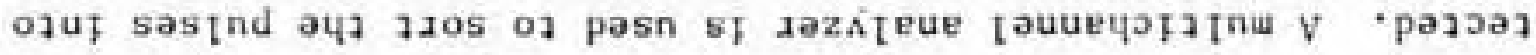

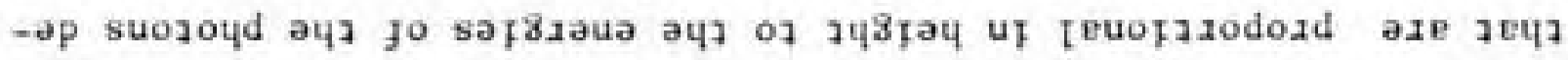

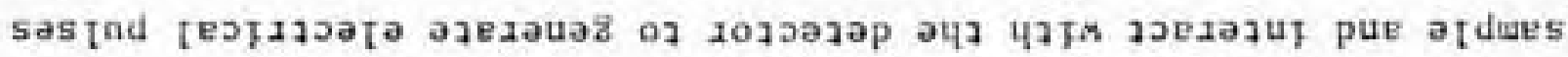

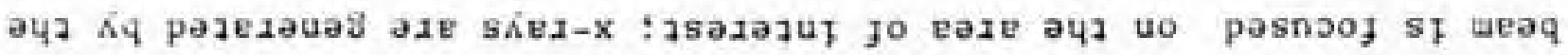

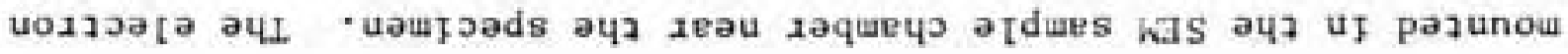


$x$-rays from a considerable volume of solid naterial. A number of workers have dealt with the problem of calculating the bean spread within a non-porous solid of homogenous composition, primarily with respect to electron probe applications $(5,6,7)$. The extent of spreading is a function of the voltage used to generate the electron beam, of the beam current, and of the density and chemical composition of the specimen. Russ and Kibaya (8) measured the effective spread of the electron beam in an SEI, using stalnless steel specimens. For the FeKa peak, they found x-rays generated from an effective diameter ranging from 0.3 um for $15 \mathrm{keV}$ excitation and low beam current, to as much as 5 fr for 50 keV excitation and very high beam currents. In the present work, it is estimated from calculations based on two of the above treatments $(5,8)$ that the effective diameter for $x$-ray generation for the elements of interest ( $\mathrm{Ca} \mathrm{Ka}$ and less energetfc radiation) is of the order of $1.5 \mathrm{\mu m}, 1$.e. that the radius of effective influence of a stationary electron beam is about 0.75 um from the impacted point. These calculations assume that the local region is essentially solid; the presence of vold space would cxtend the dimensions of the effective zone.

\section{Experimental Deta1ls}

A11 of the analyses in the present work were carried out using a Cambridge Instrument Company Stereoscan Ila scanning electron mfcroscope fitted with a Kevex Corporation lithium-drifted stifcon detector unit coupled to a multichannel analvzer and display unit manufactured by the Northern Scientific Corporation. The energy resolution of the $x$-ray un1t was approximately $215 \mathrm{eV}$. Spectmens were inftally prepared for SEM observation usine a two step electrical conductivity coating, carbon and a gold-palladium alloy. Subsenuently It was determined that a spectral line of gold interfered with the analysis for sulfur. and clironlum was substituted for the goldpalladium without significant loss of apparent resolution capahility in SHM observation. 
The specimens used were of two kinds. Standards of compounds of known stolchiometry were available as powders, and were prepared for observation and analysis by mounting the powders on doublecoated cellophane tape previously affixed to the SEM specimen stubs. Specimens of hardened cement paste were fractured after drying to yield blocks of the order of $1 \mathrm{~cm}$ on a side, which were mounted to the stubs with Duco cement and then coated. Sllver conducting paint was applied judiciously to assure conduction to ground.

In genera1, the ohservations consisted of a) SEY observation of the specimen. and selection of local regions for analysis, b) photographing the region, c) placing the beam spot on the preselected site and adjusting the electron beam for efficient $x$-ray production, and d) counting. $A 11$ of the observations were carried out at $20 \mathrm{keV}$.

To secure proper $x$-ray analyses it is faportant to assure a direct stralght-line path is avaflable between the spot chosen for analvsis and the x-ray detector. Any overhanging or blocking regions of the rough fracture surface that the $x$-rays would have to pass through would alter the relative quantities of the photons of different energies by differential absorption and fluorescence effects. With proper operator care, it is usually possible to avold such prohlems by tilfing or rotating the specimen stape.

\section{Calibration and Analysis Scheme}

Since the objective of this study was to determine the approximate chemical composition of local repions on a rough, porous, complex fracture surface, it was decided to set up the analvsis in terms of ratios rather than to attempt to determine absolute compositions. In conformity with the ustual conventions in cement chemistry, the ratios are expressed as oxide ratios rather than as element ratios.

A sufte of pure, wel1-characterized samples of synthetic cement minerals and cement hydration conpounds was assembled by the author through the courtesy of L. E. Copeland and hts assoctates of the 
Fortland Cenent Association and of Horace Berman, formerly of the Sational Dureau of Standards. These were supplemented by several additional samples prepared in the author's laboratory and by a few pure minerals. These propective standards were checked by $x$-rav diffraction, exanined critically by SEM observation to Insure that they appeared nicroscopically honogeneous, and then tested by repeated $x$-ray spectra talen on different grains. All but a few proved quite honoeeneous on a local scale and vere judged sutcable for use.

X-ray spectra were obtafned for each of these standards in the form of euantitative count readings in each of two hundred channels covering the energy range from zero to $10 \mathrm{keV}$ in steps of $50 \mathrm{el}$ ner channel. Each spectrun was normally accurulated for a perfod of 100 seconds of the electron bean being positioned on a single spot. The bean current used vas sufficfent to accunulate on the order of ten to chirty thousand counts in the channel narking the center of the Ca Ka peak. For each spectrum, the counts of the channets markine the centers of the Ka peaks of calcium, silicon, sulfur, and aluminum vere noted. So background corrections were made. Fat los of these Rross peak hetghts were conputed for calcium compared wth each of the other elements. Averages of these gross peak helpht count ratios were complled frop replicate spectra taken from 4 to 5 separate grafns of each compound. The resulting average count ratios were plotted agalnst the known oxide composition rattos of the standards to yleld the calihration curves of Figures 2, 3, and 4, respectively.

A number of otservations are evident with respect to these figures. In al1 cases the count ratios are 11 nearly related to the composition ratios, at least in the range of compositions examined. The slopes of all of the strafght lines are reasonably close to unity. The Intercepts are small for the $\mathrm{CaO}_{\mathrm{S}} \mathrm{SIO}$, and $\mathrm{CaO} / \mathrm{SO}_{3}$ comparisons, but falrly large for the $\mathrm{CaO} / \mathrm{Al}_{2} \mathrm{O}_{3}$ calibration 11 ne. Compounds having the sane composftion ratios for particular pafrs of elements but different residnal compositions shov essentially identical 
count ratios for the common elements. For example, tetracalcium aluminate-13-hydrate $\left(\mathrm{C}_{4} \mathrm{AH}_{13}\right)$, tetracalclum aluminate monocarbonate11-hydrate $\left(\mathrm{C}_{3} \mathrm{~A} \cdot \mathrm{CaCO}_{3} \cdot 11 \mathrm{H}_{2} \mathrm{O}\right)$, and tetracalclum aluminate monosulfate12-hydrate $\left(\mathrm{C}_{3} \mathrm{~A} \cdot \mathrm{CaSO}_{4} \cdot 12 \mathrm{H}_{2} \mathrm{O}\right)$ all have $\mathrm{CaO} / \mathrm{Al}_{2} \mathrm{O}_{3}$ ratios of 4.0 and all have approximately the same count ratio, as indicated in Figure 4. This observation suggests that interelement effects are not likely to be troublesone in the cement systems.

The utility of these calibration curves for determining the local composition of particles in cement pastes and other complex systems is apparent, provided that the deviations of individual trials from the mean count ratios is not too great. That this is the case is indicated by the data for repeat counts tabulated in Table I, which conveys the ranee of Individual variation normally encountered, and the repeatablity of the counting process at different times. While no formal statistical analysis of this and much additional complementary data was attempted, it seems clear that the precision of the determinations is nute satisfactory for the purpose proposed. In this connection. due caution always needs to be paid to the provision of a clear path from the site selected for observation to the $x$-ray detector, as previously mentioned. Also, it was observed that occastonallv electrical malfunction or instrumental error produces a widely deviant count ratio; however, repeat trials on a single spot or movement to another spot in the same particle usually discloses the devfation and the offending count ratio may be 1gnored. Since under approntiate conditions a single count can be completed in a few minutes replfcate analyses do not constitute a hurden.

\section{Analyses of Hydrated Cement Pastes}

In the following section, a number of micrographs 111 ustrating various characteristic features of hydrated cement pastes are discussed in terms of the analysis secured from particular spots, as indfcater by the markers. Fach cited analusis represents an average of three to flve replfcate determinations on the same spot. The actual composttional 
ratios cited were calculated from the count ratios by 1 inear equations fitted the calibrations previously given. Analyses representing significant extrapolation from the range of the calibration curves are reported as approximations to the nearest one-half rat 10 unit. The validity of these approximations is unknown, but the relative values should be correct.

Figure 5 shows a characteristic microstructure found in most hydrated cement paste, a spherul1tic cluster of calcium slificate hydrate, found in an $0.6 \mathrm{~W}: \mathrm{C}$ rat 10 paste hydrated for 185 davs at $40^{\circ}$. Yorphological units of this type have been prevlously reported in cement paste (9) and in pastes of dicalcfum sflicate (17). and their growth was explained by W111amson (11) on the basis of constitutional supersaturation. The analysis indicates a CaO/S10, mole ratio of 2.08 , substantially that of dicalclum sillcate. There Is a definite spectral response for sulfur, and the apparent $\mathrm{CaO} / \mathrm{SO}_{3}$ ratio is about 13.5. Judged from a linear extrapolation of the calibration curve of Figure 3. thile no direct caltbration is availahle for the $\mathrm{StO}_{2} / \mathrm{S} n_{3}$ mole ratio, the two ratios above lead alpebrafcally to an estinate of 6.5 for this ratio. Copeland et al (12) determined that sulfur added to $\mathrm{C}_{3} \mathrm{~S}$ in the form of gvosum was incorporated in the resulting calcfum sflicate bydrate gel in amounts correspondins to a maxtmum $\mathrm{S}_{2} n_{2} / \mathrm{SO}_{3}$ mole ratin of 6.3 . The nearly precise agreement of the present data is prohahly fortuftous. Nevertheless, as wf11 he aprarent subsequently, sulfate contents of this order of magnitude are unfversal in the calcium sflicate hvdrate gel areas analyzed. This is in accord with the nrevious indications by Kalousek (13) and by Copeland et al that this element is normally incorporated in solfd solution within the gel structure.

Figure 6 shows a ffeld consisting mostly of clusters of relativelv short flbrous particles, the clusters befng of the order of 2 um in diameter. Such clusters seem particularly characterfstic of observations made in the earlier stages of hydration. The paste represented here is an 0.6 water zement ratio paste hydrated for 7 
days at $6^{\circ} \mathrm{C}$. Such fibers are sometimes seen to grow from the surface of cement or $\mathrm{C}_{3} \mathrm{~S}$ grains, but in the present case $1 \mathrm{t}$ appears that they represent the growth of precipitation nuclei from solution. The analyses of the two points indicated on the micrograph yield $\mathrm{CaO} / \mathrm{S}_{1} \mathrm{O}_{2}$ ratios of the order of 2.3 , and $\mathrm{CaO} / \mathrm{SO}_{3}$ ratios similar to that of the longer-fibered spherulites of Figure 5. The very thin flat filmy plate observable in the upper right-hand corner is apparently calclum hydroxide, although a specific analysis of this feature was not made.

The presence of calcium hydroxide within the hardened cement paste is noticeable even at early ages. F1gure 7 shows an 0.6 water:cement ratio paste hydrated at $24^{\circ} \mathrm{C}$ for 1 day. The roughly half-micrometer thick plate in the center of the figure, marked by the erect triansle, is clearly calcium hvdroxide. Somewhat surprisingly the rather large needle-shaped particles just above and to the right of this plate (Indicated by the inverted triangle) also seem to be calctum bydroxide. Fxamination of another area marked by such needle-shaned particles in the extreme left-hand portion of the flgure, rade hy rastering a very small square pattern covering the area of contact between the two crossed needles, gave a substantially identical analysis. It is apparent from the lack of sulfur that these particles are definftely not ettringite, and the lack of silica suggests that they are not a variety of calclum sillcate hydrate.

The analysis of the calciun s1licate hydrate gel region near the bottom of Figure 7 shows a $\mathrm{CaO} / \mathrm{SO}_{3}$ ratio substantially identical to that previously indicated as characteristic for gel, hut a sonewhat higher $\mathrm{CaO} / \mathrm{SIO}_{2}$ ratio of 2.9 . It appears that the $\mathrm{CaO} / \mathrm{SiO}_{2}$ ratio to be found in the gel varies usually between 2 and 3 . Figure 8 shows a typical example of a fleld from another young paste $(0.6$ water:cement rat1o, hydrated 4 days at $6^{\circ} \mathrm{C}$ ) in which 1 ncal analyses Indicate $\mathrm{CaO} / \mathrm{SIO}_{2}$ ratios of 2.9 and 2.3 , respectively in adfacent regions. 
As cement paste matures calcium hydroxide becomes an increasingly prominent constitutent. Large crystalline masses grow through regions of the paste, incorporating previously existing particles of pel and of unhydrated cement. The crystals of ten give no apparent indication of the presence of inclusions from the smooth appearance of their surfaces, and it is true that in some areas such inclusions are rinor in amount. One good indication of the presence of such hidden fnclusions seems to be the detection of sulfur radiation from the suspected area. It seems clear from the previously cited analysts, and has heen abundantly confirmed by many addftional analyses, that sulfur is always present in calcium silicate hydrate gel generated from sulfateinterground portland cement. The analyses of Figure 7 and other strilar results suggest that sulfur is usually excluded from the pure crystals of calcium hydroxide formed at early stages of hydration. Thus the detection of sulfur in a massive calcium hydroxide zone 1mplies that pel formed inftally and was later encapsulated by the growine lime crystal. Of course, the presence of significant amounts of sflica within the seemingly pure 11 nie crystal also serves to signal the presence of gel, and the combination of the two in roughly the approprlate proportions for gel seenis to provide a clear indication of tte presence.

Figure 9 shows an indication of a more or less typical local region of calclum hydroxide growth in mature paste. The specimen is an 0.6 waterfcement rat 10 paste hydrated for 185 days at $40^{\circ} \mathrm{C}$. The large blocky crystal in the upper half of the figure (presumably broken in two during the fracture incident to preparation of the specimen), shows visible rel inclusion. It does, however, show detectable sulfur and an apprectable silica content. The flat appearing surface of the lime crystal in the lower left-hand portion of the figure (indfcated by the triangular nark) is close to apprarent layers of gel; thus the sulfur and sflica contents are not particularly helpful in interprctation. The analysis for the gel itself, centered at the square mark, shows a composition within the 
range for gel previously observed, although the sulfur content appears slight 1y lower than the average.

Figure 10 conveys a more or less simflar picture. This is a field from an 0.4 water:cenent rat 10 paste hydrated for one ycar at $6^{\circ} \mathrm{C}$. The analysis for the 11 me crystal (triangular mark) is simflar to those of Figure 9, as is the analysis for the gel region (round mark), except that the sulfur content of the gel in this case is a little higher than usual.

An idea of the extensive interminglinf of calcium hydroxide and cement gel in many areas of mature paste is provided in the next two figures. Fipure 11, taken from a paste of water:cement ratio 0.4 hydrated for 1 year at $6^{\circ} \mathrm{C}$, yielded analyses indicating that the upper, massive appearing hroken crystal is largely pure calcium hydroxide: that the smooth, flat area in the foreground is calclum hydroxide with some underlying or incorporated gel: and that the porous areas indicated by the trlangular mark are essentially calcium s1licate hydrate gel With a little admixed 1ime. Figure 12 was taken from an 0.f water: cement ratio paste hydrated for 318 days at room temperature. This particular specimen was coated with gold-palladium, so that sulfur analysis is not avallable, but the calcfuntsilfca ratios are of interest. An aralysis made on an area of gel just above the f1gure cave a Ca0/S10 2 ratio of 2.9 , within the normal range of gel previously indicated. The two analyses indicated for pel areas near the bottom of the fipure yielded ratios somewhat higher than the normal range, close to 4 : suggesting that some extra lime is contributing to the count. Four closely spaced analvses indicated on the fractured stratum emerping fron the mass at the right hand side of the picture all vield $\mathrm{Can} / \mathrm{S}_{10}$ ratios between 7 and 11 . Tils confirms the visual indication that desplte the smooth surfaces present (where the plates are not fractured), many areas that appear to be pure crystals of calcium liydroxide to in fact incorporate s1gniffcant amounts of Rel. 
It is generally appreciated that hydration of portland cement is of ten less than complete, even after prolonged periods. Thus residual unhydrated portions of cement grains ought to be visible occasionally in fracture surfaces of pastes. Comparatively few such grains were fdentified in the present study.

When an Individual remnant grain was found, it was not always evident whether the grain represents the original unchanged cement mineral or a pseudomorphic "inner" hydration product. Figure 13 shows such a grain. The analysis indicates that no sulfur is detected, and the $\mathrm{CaO} / \mathrm{SHO}_{2}$ ratio otserved is sufficiently close to 3 to suggest that it is a remant grain of $C_{3}$. The paste is young enough ( 0.6 water:cement ratio, hydrated at $6^{\circ} \mathrm{C}$ for 4 davs) that this is not unreasonable. On the other hand there anpears to be at least a surface laver of very fine, mostly needle-shaped particles, which appear to Indicate at least partial hydration. Figure 14 is a grain found in a much more mature paste $(0.6$ water: cement ratio, hydrated for 185 days at $40^{\circ} \mathrm{C}$ ) which appears to be $B-C_{2} S$ from the analysis. However, both areas analyzed yteld indications of more than a trace of sulfur, a feature not easily explained.

The relationship that may be developed at the perfeter of a hydrating cement frain and the nature of reaction products produced there has heen a subject of considerable interest. Williamson (10) has discussed the formation of 'inner' hydration nroduct within the perimeter of the original grain which is sald to constitute a zone of pseudomorphous livdration: this is sald to be surrounded by a so-called "columnar" zone of outer product frowlng outward from the former rim of each grain. Indications for the existence of such zones seem to be nutte rare in the many fields examined in the present research, perhaps because of overgrowth by other materfals. However, one field which appears to perhaps reflect such a situation is given In Fig. 15. for a quite Immature paste (0.f water:cement ratio, hydrated for 2 days at $6^{\circ} \mathrm{C}$ ). Fracturing of this weak paste 
has apparently disturbed the local spatial relationships considerably, hut the left-hand portion of the figure shows a wedge-shaped unit which might he taken as a piece of inner product with a portion of its $\mathrm{rim}$ of reaction product clinging above 1t. Figure 16, which shows fine detall of this area confirms the porous nature of the supposed inner product, showing pores of the order of perhaps $500 \AA$ separating poorly defined grains. The analysis for this area show no sulfur present at all, and $\mathrm{CaO} / \mathrm{SHO}_{2}$ ratios are close to 3 , suggesting that the original grain was tricalctum silfcate. Approximately half a micrometer above the "rim", analyses of the center of what might be taken as the columnar zone show that here some sulfur is present and that an enrichment in calcium has occurred. Analvses taken above the polnt where the columnar zone fades into the general calcium silicate hydrate sel groundmass show the typlcal composition for ordinary sulfate-substituted calcium silfcate hydrate gel. It should be noted that the apparent "columnar zone" is only a micrometer or so thick, much thinner than the thick columnar layers postulated by K1111amson.

\section{Discussion}

Several generalizations drawn from the analytical information presented in this paper are worthy of further discusston.

First, it was noted previously that local analyses for areas of paste identified as calcium sllfcate hydrate gel show CaD/S10, ratios between 2 and 3, except for a few areas, apparently influenced by nearly calcium hydroxide, that show even higher values. This is in contrast with estimates of $\mathrm{CaO} / \mathrm{SHO}_{2}$ ratios previonsly reported in the literature as reflecting the compositfon of gel in pastes of hydrated $\mathrm{C}_{3} \mathrm{~S}$ or $\mathrm{C}_{2} \mathrm{~S}$. In such studies the amounts of unhydrated compound and of calcium hydroxide are determined and the composition of the calcium silfcate hydrate gel calculated by difference of these elements from the known overall composition of the paste. Typical 
results are given by Kantro, Weise, and Brunauer (13), who find a range between 1.35 and 2.1 for $C_{3}$ s pastes varying in are from 1 day to more than 1 year, and a range of 1.0 to 1.8 for $c_{2} s$ pastes ranging In age fron 1 day to almost 5 years. Locher (14) reported essentially sinllar compositions for $\mathrm{C}_{3} \mathrm{~S}$ pastes, with his reported range being slight) higher ( 1.6 to 2.3$)$ if the calcium hydroxice deternination b\% TCS is tsed in the calculations. The anparent contradictien between these indirect calculations and the present local analyses on hvdrated portland cerent pastes certainlv invites further investigation.

Second1\%, it is North while reemphasizing that the areas fdentiffed as calcium silfcate hydrate gel alvays vielded measureable spectral peaks for sulfur. The feu areas, such as those shoun in Figure 16, that appeared to be "Inner" product, f,e. naterial hydrated, If at all, only by topotactic reaction did not show the presence of sulfur. Onlv reaction product penerated by a through-solution mechanfsm is thelv to incorporate an impurity such as the sulfate fon so unfformly over all regtons of the gel formed.

Finally, in contrast to the useful information derfved with respect to the distrthution of sulfur in the bydrated pastes, that obtafned in this study with respect to aluminum distribut on vas quite disappointing. The Al Ka peak is difftcult to resolve completely fron that of silicon when aluminum is present only in snall amounts. In separate $x$-ray diffraction studles of most of the pastes examined it was confirmed that both ettringlte and tetracalelum aluninate monosulfate-12-hydrate were present in sma11 anounts within the pastes examined. However, In the StI investipation areas In which the presence of these compounds vas suspected were observed only very infrenuently on the fracture surfaces ohtafned, and in reneral these areas could not be analyzed nuanttativelv. 
seens that a more elaborate analytical procedure and a spectrometer of somewhat better resolution will be required to yield meaningful information on the distribution of aluninum in bydrated cerent pastes.

\section{Conclusions}

1. Rapid identification and approximate quantitative analvsis of ofcrostructural features observed in hvdrated cerents by SIY tav be easfly accomplished by energy -dfspersfve $x$-ray spectrometer attachment to the fnstrument.

2. Patfos of gross peak hefghts observed for Ka neaks are linear functions of the corresponding ratios of elements for calefur as conpared to silfcon, sulfur, and aluminun. Interelerent effects seen not to be frportant.

3. Observed $\mathrm{CaO} / \mathrm{SIO}_{2}$ ratios for local areas telentffed as calcium stlicate hydrate gel range broadly between 2 and 3 , and are thus higher than those normally considered to be characteristic of this substance.

4. Sulfur is identified as a finor constituent in all restons identiffed as calcfum silicate hydrate pel (in hvdrated portland cement), but is not present vithin sma11, we11formed calctum liydroxide crystals. Its detection in large masses of calctum hvitoxide is an Indteation that the calcfum hydroxide has grown throuph an area in which calctur $x 11$ icate hydrate gel vas previously depessted. 


\section{Acknowledgements}

This research was supported by the Indiana State Highway Commission and the Federal Highway Administration through the Joint Highway Research Profect, Purdue University. The analytical work was carried out using the SEY and associated x-ray spectrometer facilftes of the Analytical Instrumentation Laboratory, Fngineering Fxperiment Station, Ceorgia Institute of Technology. The author expresses his gratitude to John Brown, llead of the Laboratory, and to James L. Huhbard and Larry Classman for thetr exceedingly fruitful collaboration. Thanks are due to L. F. Copeland and to Horace Berman for pifts of pure cement and hydrated cement compounds which served as analytical standards. 
RFFERENCES

1. J. C. Russ, Scanning Flectron Zicroscopy/1971 (Proc. 4th Annual S.F.N. Symposite, Chicago) 65 (1971).

2. R. S. Frankel and D. W. Attken, Applfed Spectroscopy 24 357 (1970).

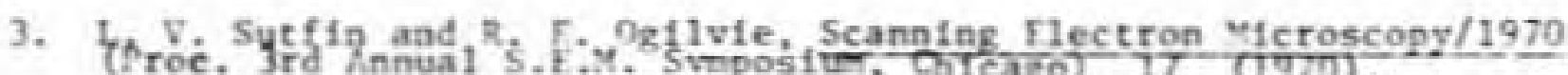

4. J. C. Russ, coordinator. Energy Mispersion X-Ray Analysis,

S.T.P. 455. Amer. Soc. Testfing and Matis.. 285 pP (1971).

5. S. J. B. Reed, X-Rar Optics and Yicroanalysts (Proc. 4th Int1. Coneress, Orsav, 1965) 339 (1966).

5. V. E. Cosslett, X-Hay. Ontics and Microanalysis (Proc-4th Int1. Congress. Orsay, 1965) 85 (1966).

7. H. I. Rishop, X-Pay Optics and Microanalysis (Proc. 4th Int). Congress, Orsay, 1965) $112(196 \overline{6})$.

8. I. C. Russ and A. Kibaya, Scanning Flectron Microscosy/ 1969

(Proc. 2nd Annual S.E.X. Symposium, Chfeago, 1969) 57 (1969).

9. S. Diamond, Scanning Electron Mferoscopy/1970 (Proc. 3rd Annual S.E.M. Symposfum, Chicago, 1970) 385 (1970).

10. R. B. W1111amson, Sol1dification of Portland Cerent, Report No, UC-SFSY 70-23, Untversity of Calffornla, Berkeley 109 DP (1970).

11. D. B. W1114amson, I. Crystal Crouth 3,4787 (1968).

12. L. E. Copeland, E. Bodor, T. N. Chang, C. I1. Wetse, J. P.C.A. Res. and hev, labs. 961 (1967).

13. D. L. Kantro, C. H, Welse, and S. Brunauer, Symposfum on Structure of Portland Cenent Taste and Concrete, Hithvay Mes. Bd. Specfal Report 90, 3ी० $(1965)$.

14. F. W. Locher, Symposium on Structure of Portland Cement Paste and Concrete, Fiphway Res. Bd. Spectal Report 90. 300 (1966).

15. G. L. Kalousek, Materfals Sesearch and Standards 5292 (1965). 
TABLE 1

I1lustration of the Typical Variation of Individual Count Rat fos $\mathrm{Ca} \mathrm{Ka/S} \mathrm{Ka}$ Tatios in Ettringite

\begin{tabular}{cc} 
July 1,1970 & Juty 28,1970 \\
\hline 2.01 & 1.95 \\
1.93 & 1.98 \\
1.95 & 1.95 \\
1.91 & 1.99 \\
$\ldots$
\end{tabular}

Ettringite II (PCS)

July 30, 1970

1.98

1.91

1.98

(....

$\ldots$

Aver. 1.96

Aver. 1.95

Aver. 1.96 


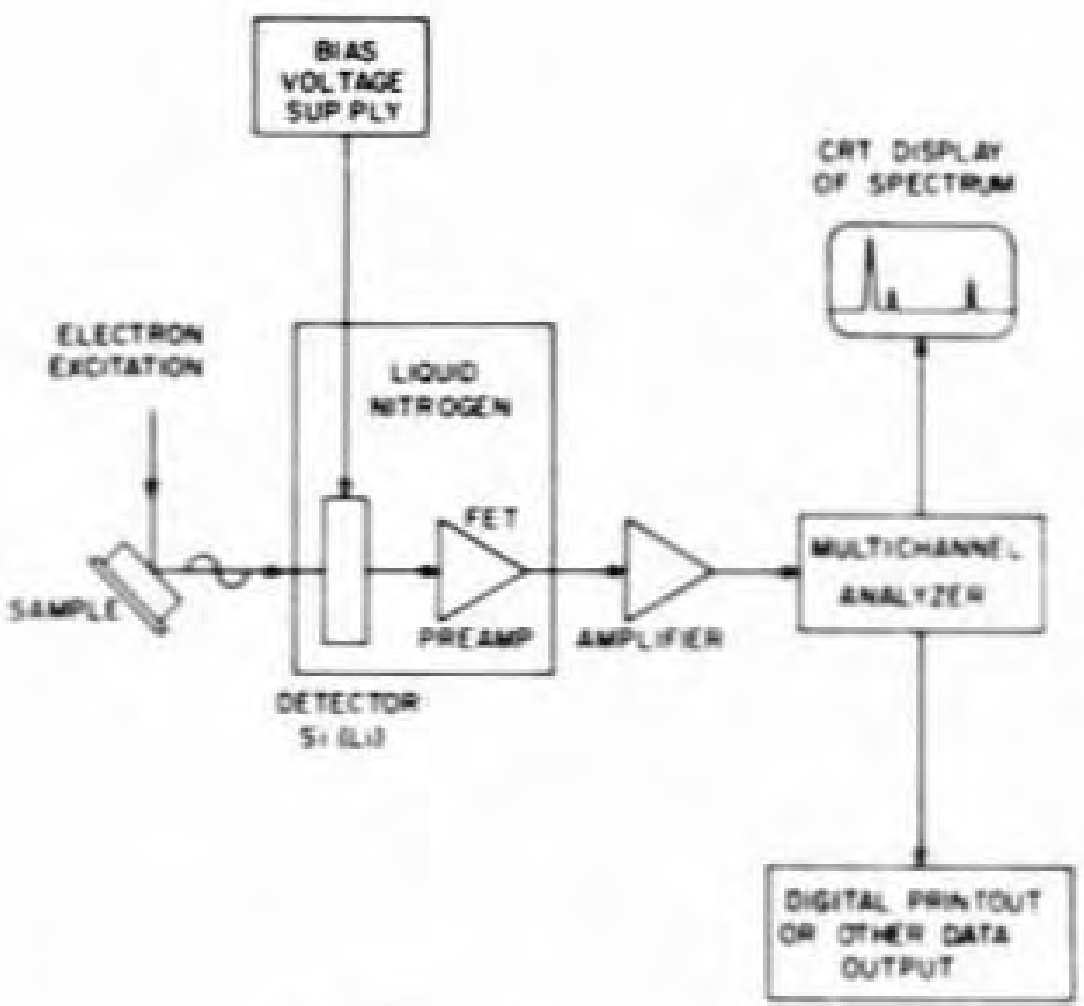

FIG. 1 Schematic diagram of energy-dispersive $x$-ray spectrometer.

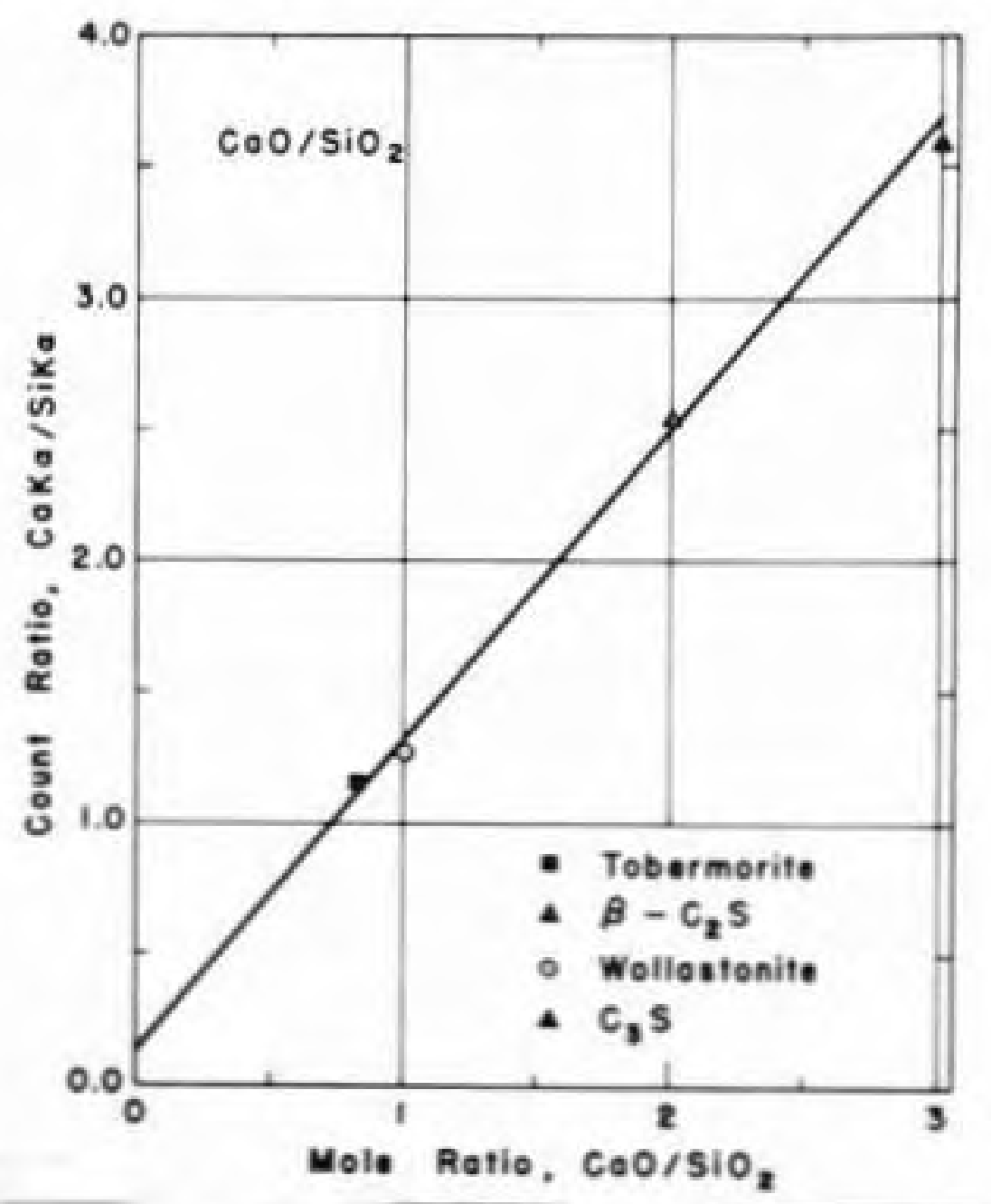

FIC. 2 Calibration for determination of $\mathrm{CaO} / \mathrm{SiO}_{2}$ ratio. 


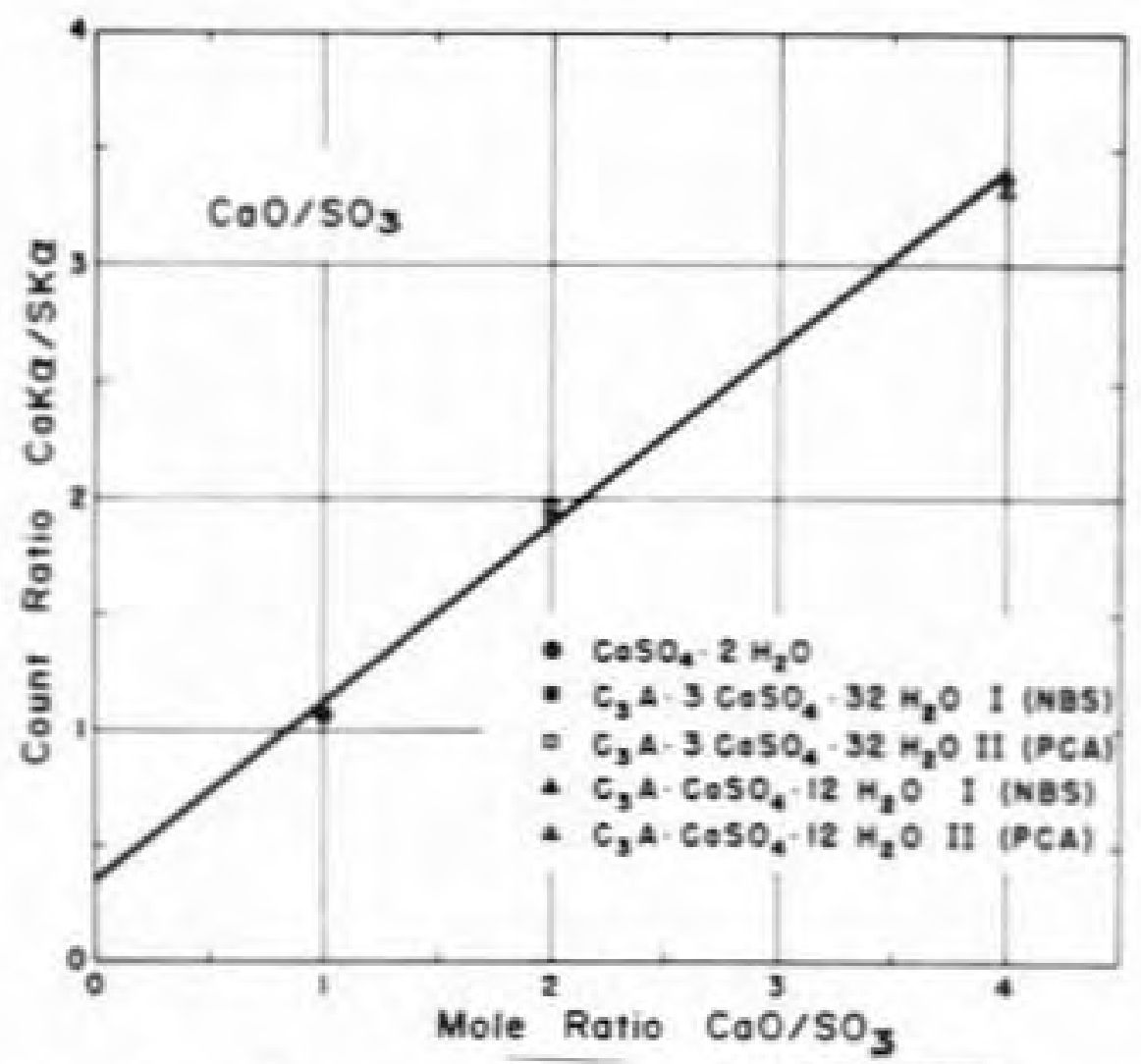

FIC. 3 Calibration for determination of $\mathrm{CaO} / \mathrm{SO}_{3}$ ratfo.

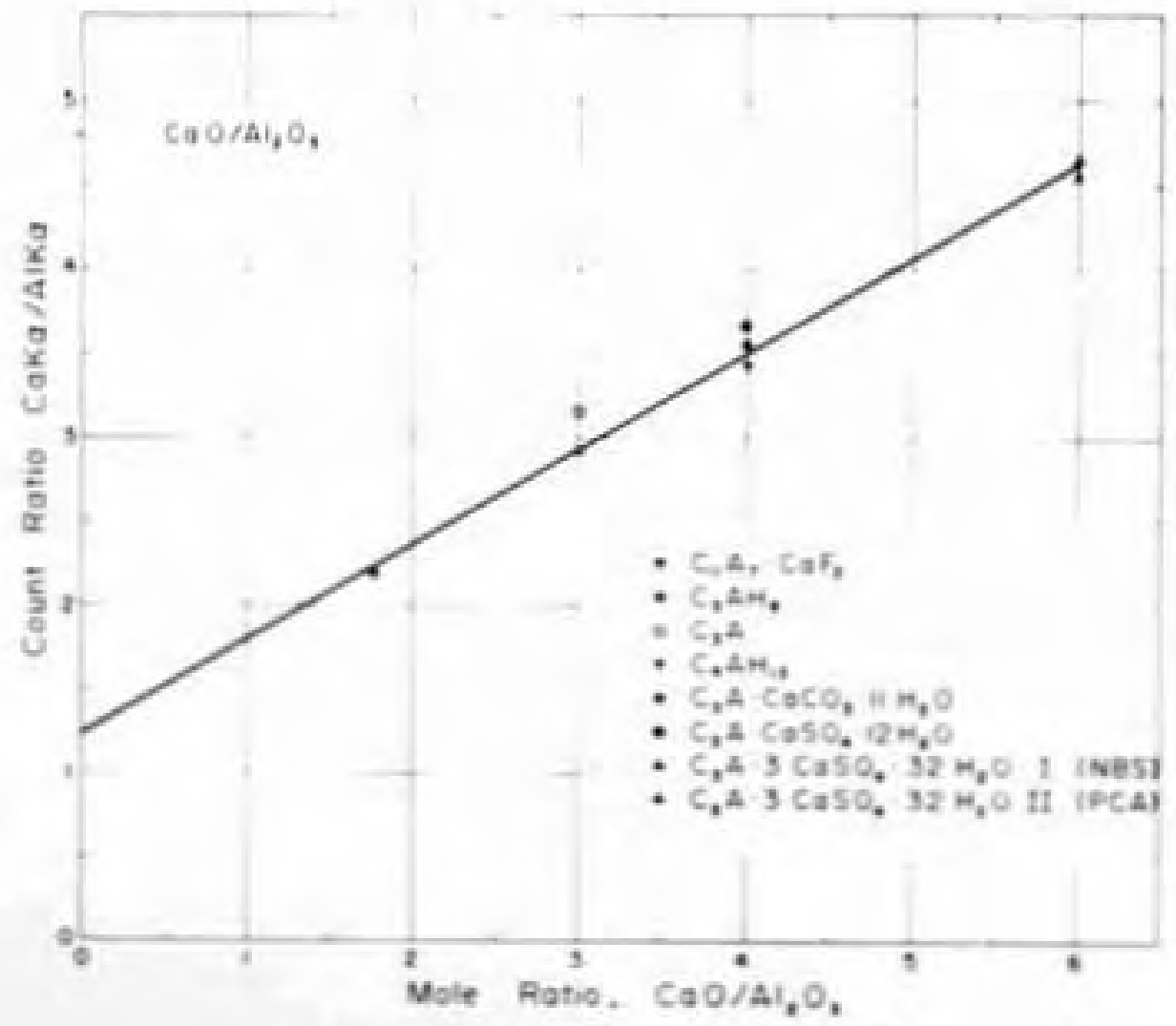

FIG. 4 Callbration for deternination of $\mathrm{CaO} / \mathrm{Al}_{2} \mathrm{O}_{3}$ ratio. 


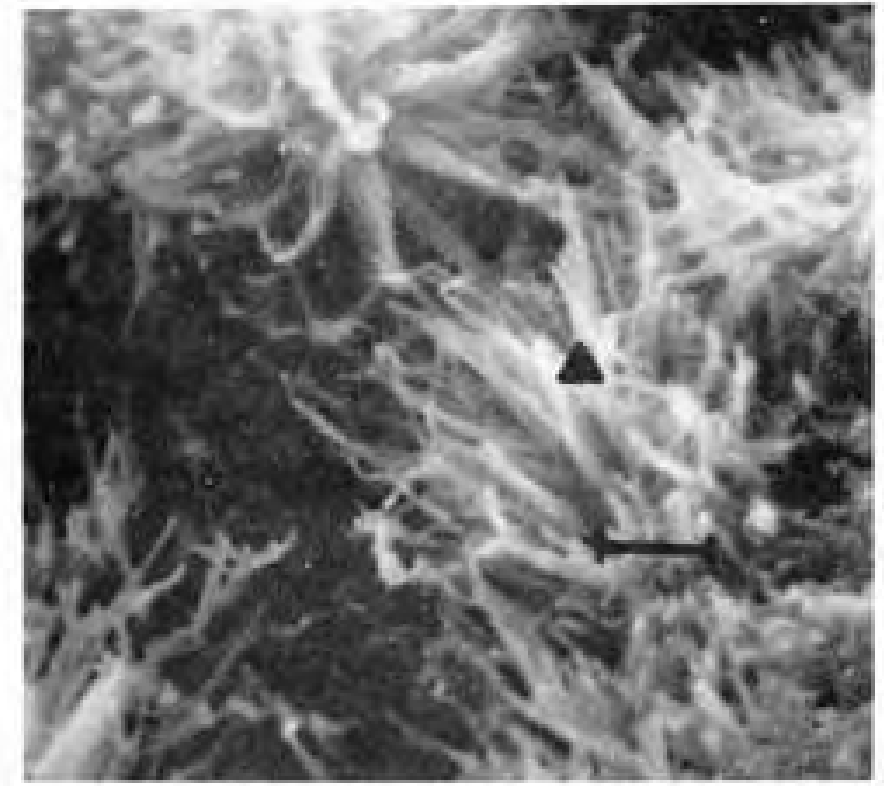

$$
\Delta \quad \frac{\mathrm{CaO} / \mathrm{SiO}_{2}}{2.0 \frac{2}{8}} \frac{\mathrm{CaO} / \mathrm{SO}_{3}}{13.5}
$$

FIG. 5

Spherulftic cluster of calcium silicate hydrate gel. W:C 0.6, hydrated 185 days at $40^{\circ} \mathrm{C}$.

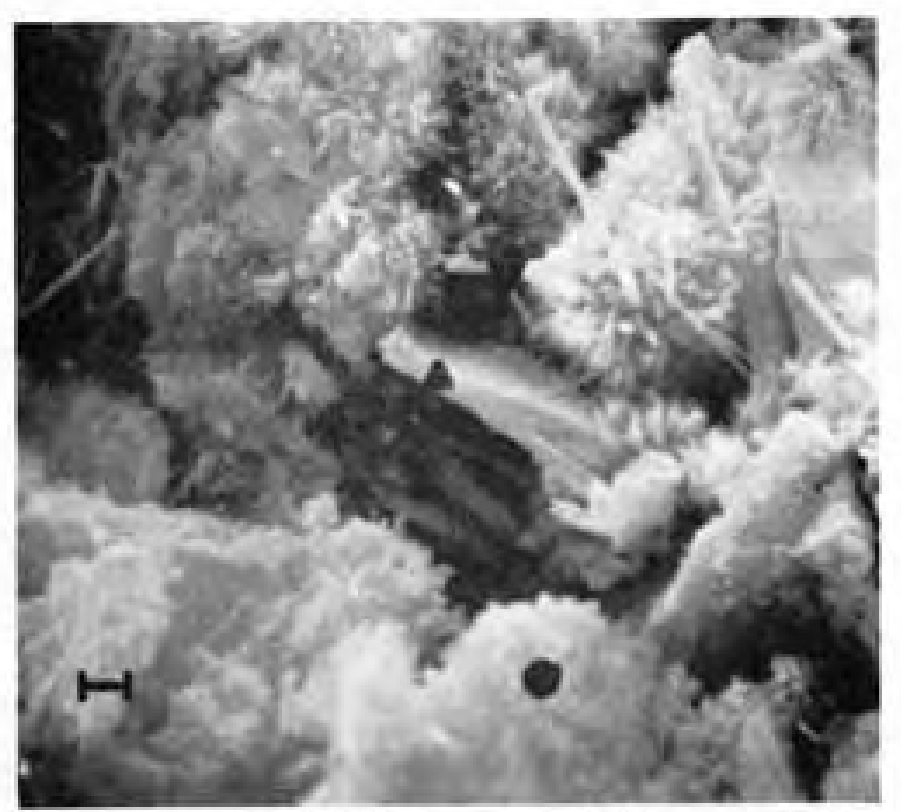

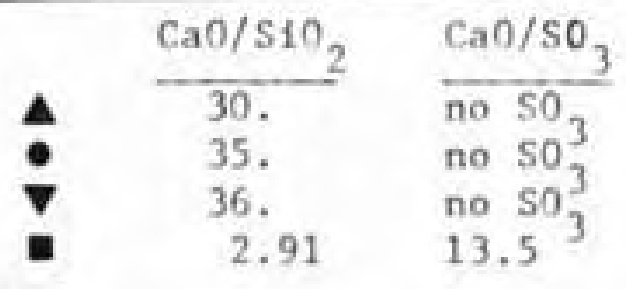

FIG. 7

Calcium hydroxide plates formed at early stage of hydration. W:C 0.6 hydrated 1 day at $24^{\circ} \mathrm{C}$.

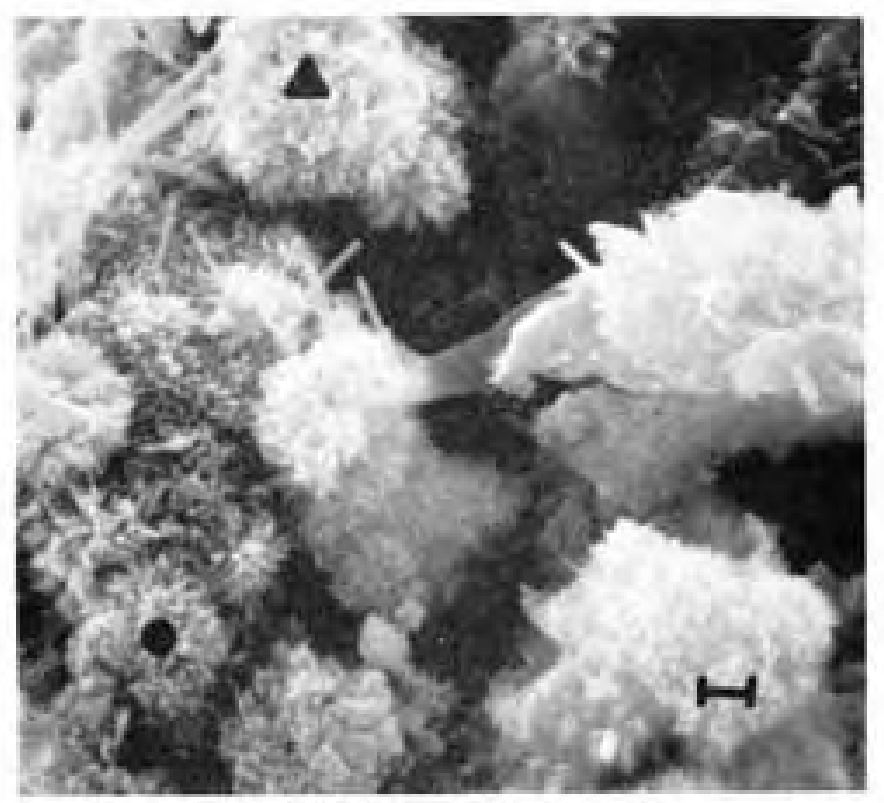

$$
\text { - } \frac{\mathrm{CaO}_{\mathrm{SiO}}}{2.42} \frac{\mathrm{CaO}_{2} / \mathrm{SO}_{3}}{2.27} \frac{13.5}{12.5}
$$

FIG. 6

Short-fibered clusters of calclum sillcate hydrate gel. W:C 0.6 , hydrated for 7 davs at $6^{\circ} \mathrm{C}$.

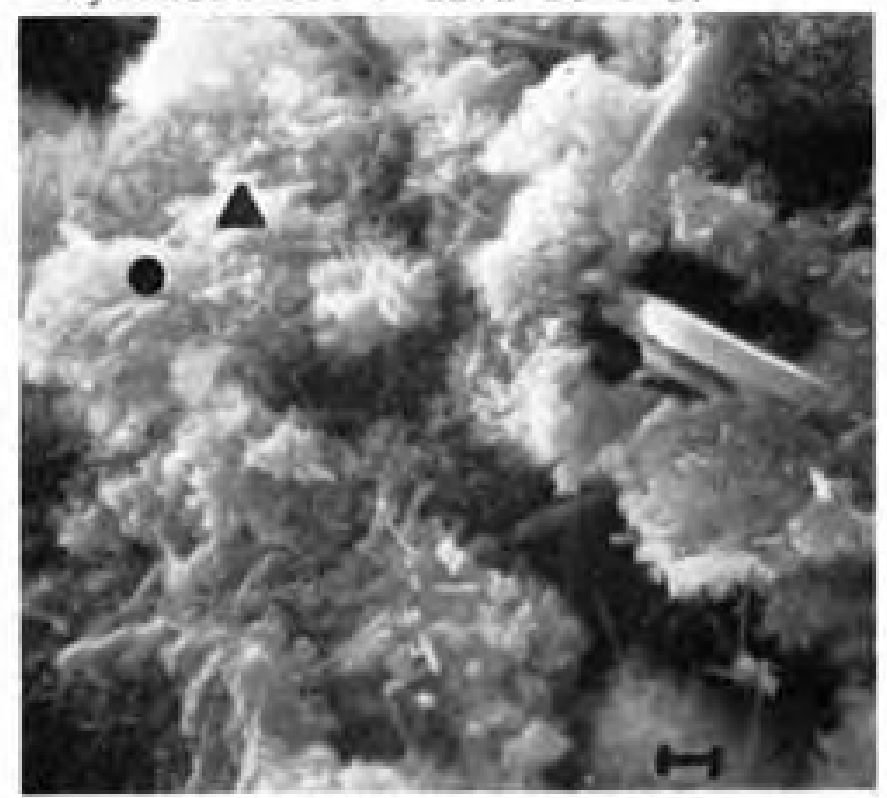

$$
\text { - } \frac{\mathrm{CaO} / \mathrm{S}_{10}}{2.88} \frac{\mathrm{CaO}_{2} / \mathrm{SO}_{3}}{12 .}
$$

FIG, 8

Calcium silicate hydrate gel. W:C 0.6 , hydrated 4 days at $6^{\circ} \mathrm{C}$. 

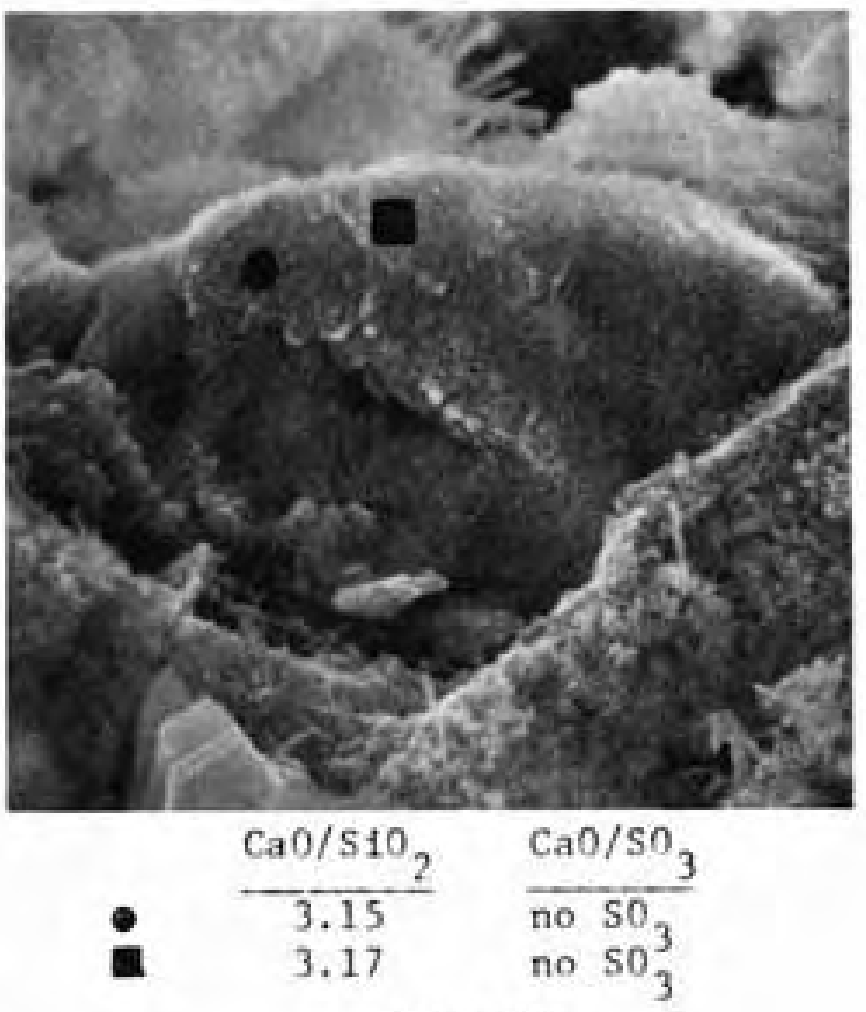

FIC, 13

Remnant grain of $\mathrm{C}_{3} \mathrm{~S}$. $W: \mathrm{C} 0.6$, hydrated for 4 days at $6^{\circ} \mathrm{C}$.

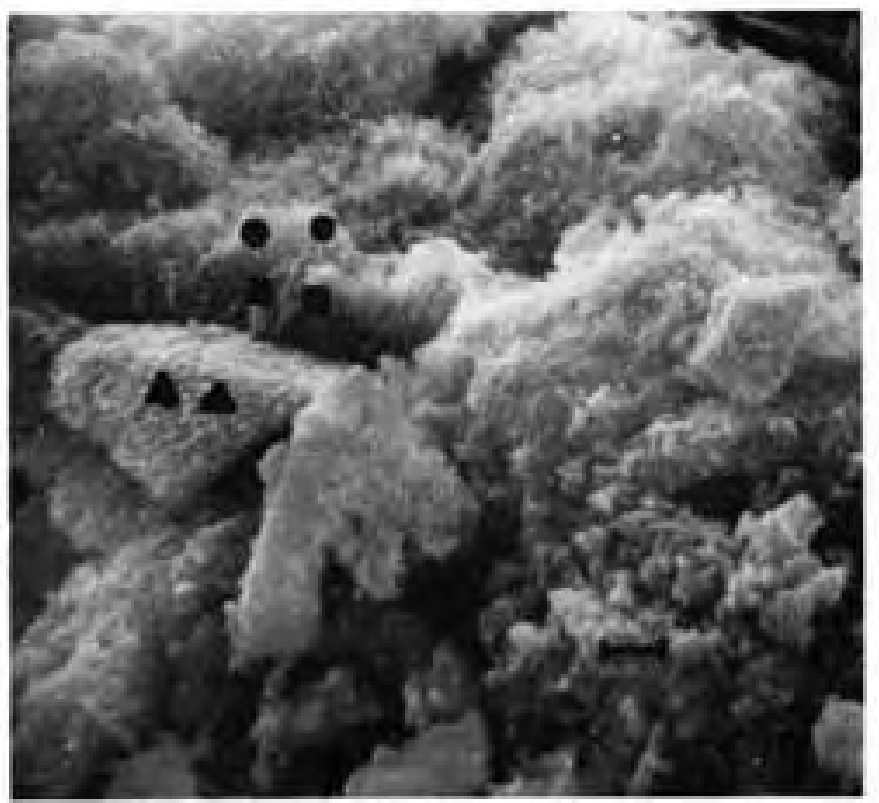

FIG. 15 (Above)

Region surrounding possible fragment of "Inner product" with apparent columnar zone above. w:C 0.6 , hydrated 2 days at $6^{\circ} \mathrm{C}$.

FIG. 16 (R1ght)

Higher-magnification view of area outlined above.

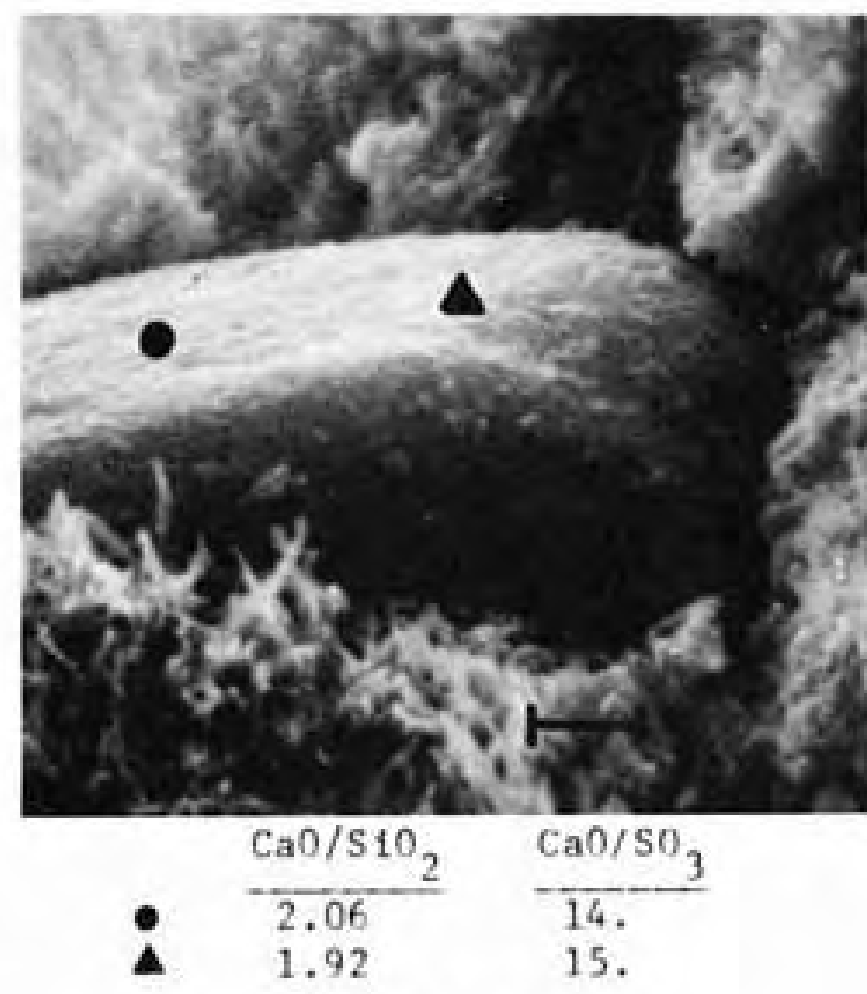

FIG. 14

Apparent remnant grain of $p-C_{2} S$. $W: C 0.6$, hydrated 185 days at ${ }^{2}$ $40^{\circ} \mathrm{C}$.

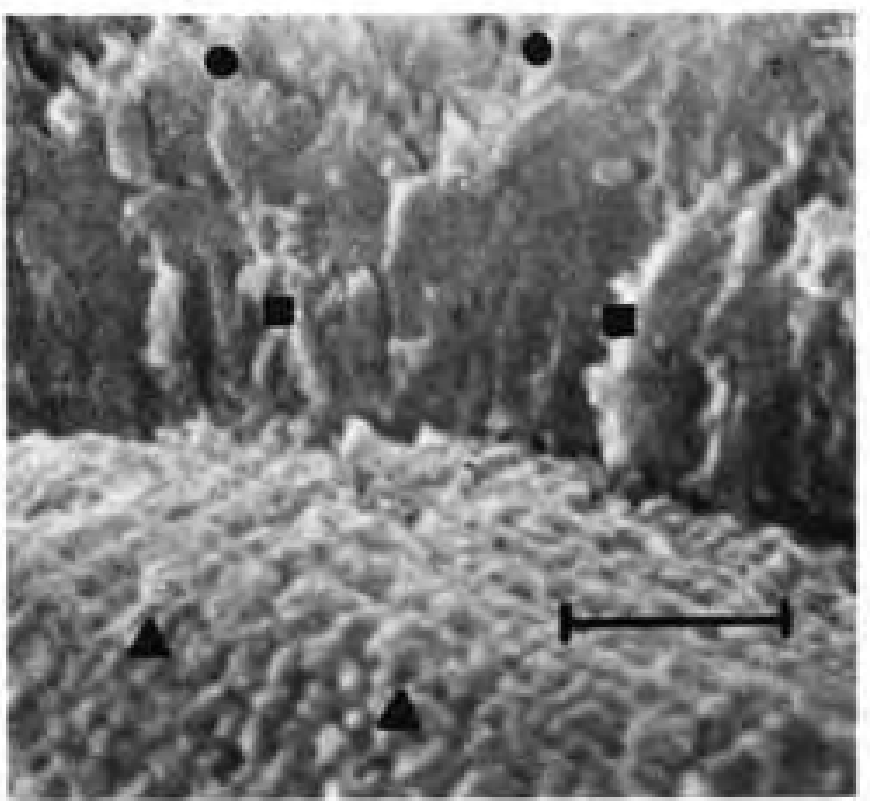

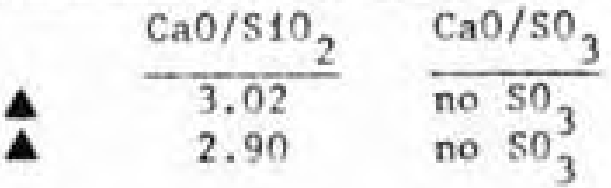
- $3.54 \quad 19.5$
- $2.48 \quad 12$.
$\begin{array}{lll}-2.48 & 12.5\end{array}$ 


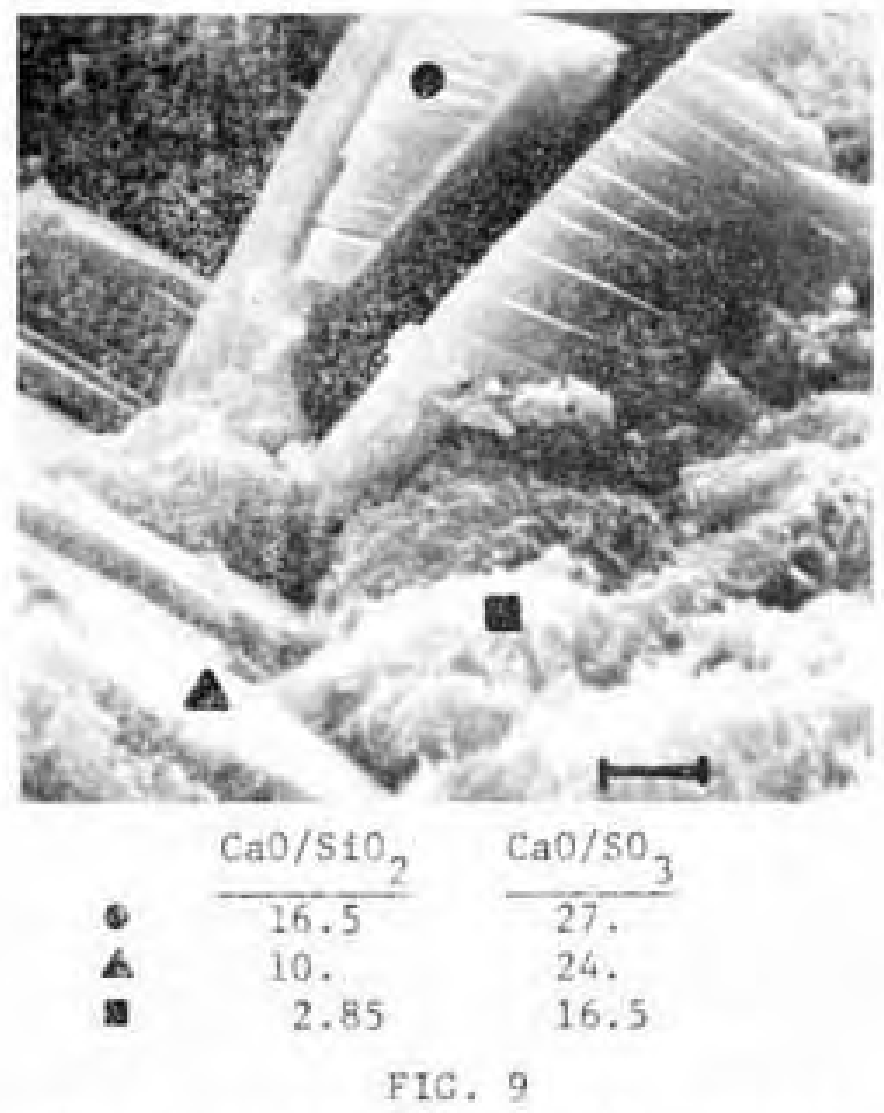

Massive calelum hydroxide crystal. $\mathrm{W}: \mathrm{C} 0.6$, hydrated 185 days at $40^{\circ} \mathrm{C}$.
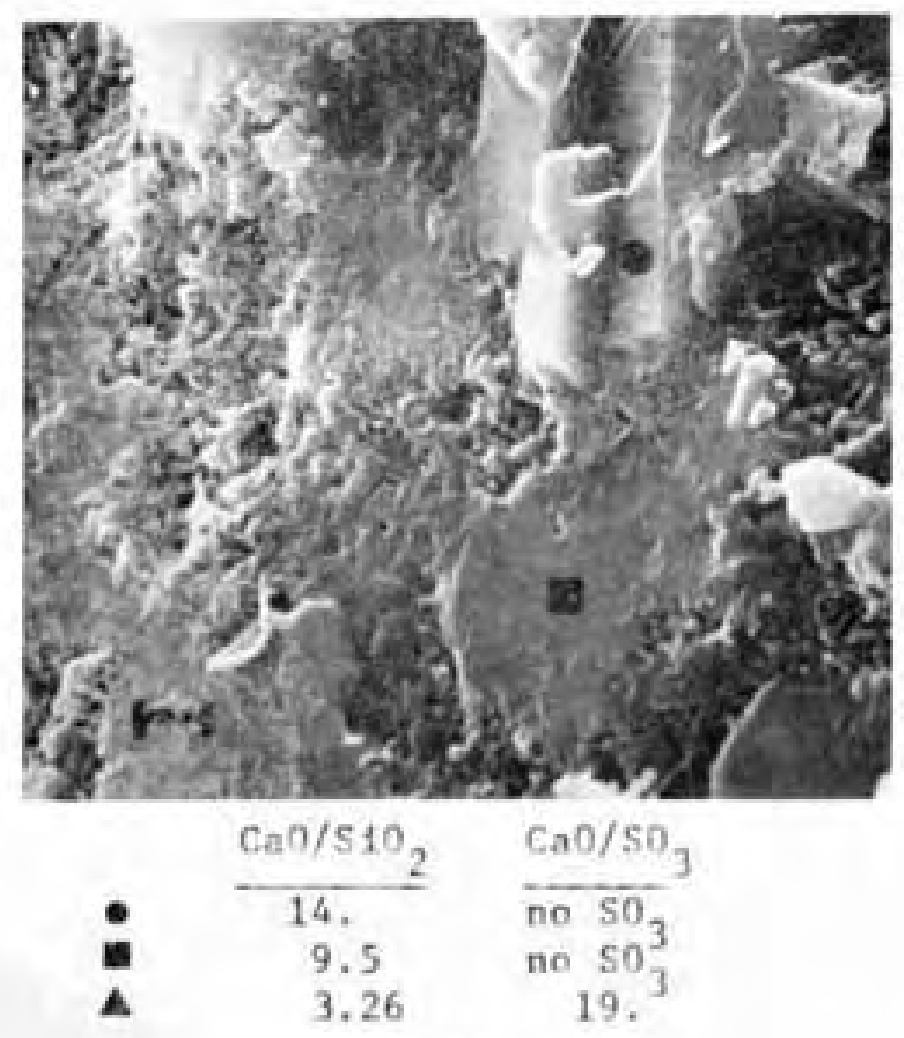

FIG. 11

Intermingling of calcium hydroxide and calcium silfcate hydrate gel. $W: C 0.4$, hydrated for 1 year at $6{ }^{\circ} \mathrm{C}$.

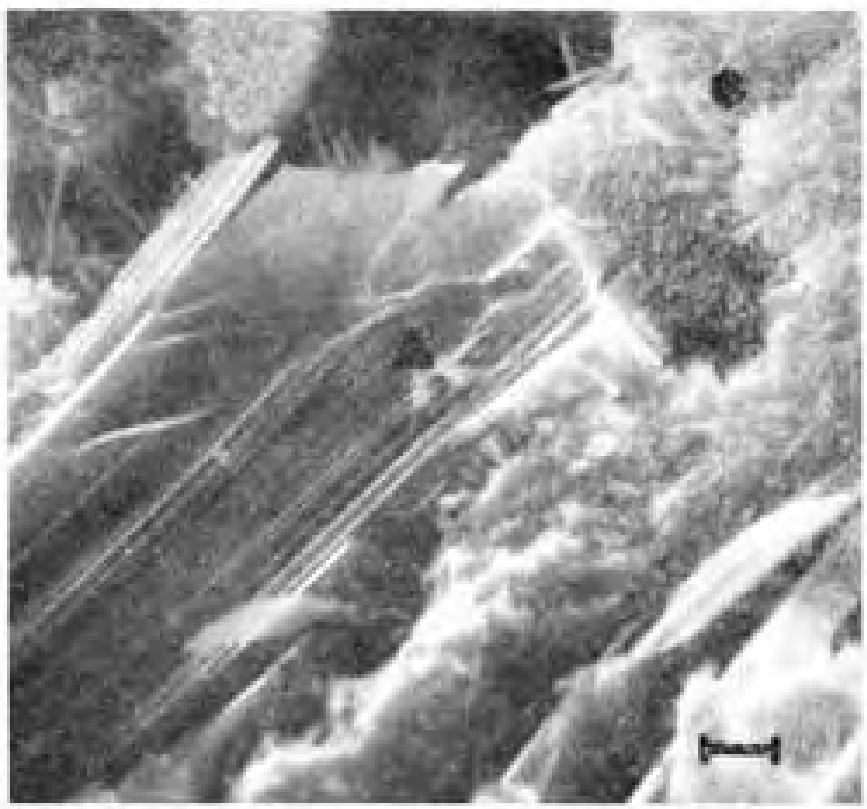

$$
\text { - } \frac{\mathrm{CaO}_{\mathrm{SHO}}}{13.5} \frac{\mathrm{CaO} / \mathrm{SO}_{3}}{2.72} \frac{2.5}{9.5}
$$

FIG. 10

Calcium hydroxide crystal growing through calcium silicate hydrate gel $W: C 0.4$, hydrated for 1 year at $6^{\circ} \mathrm{C}$.

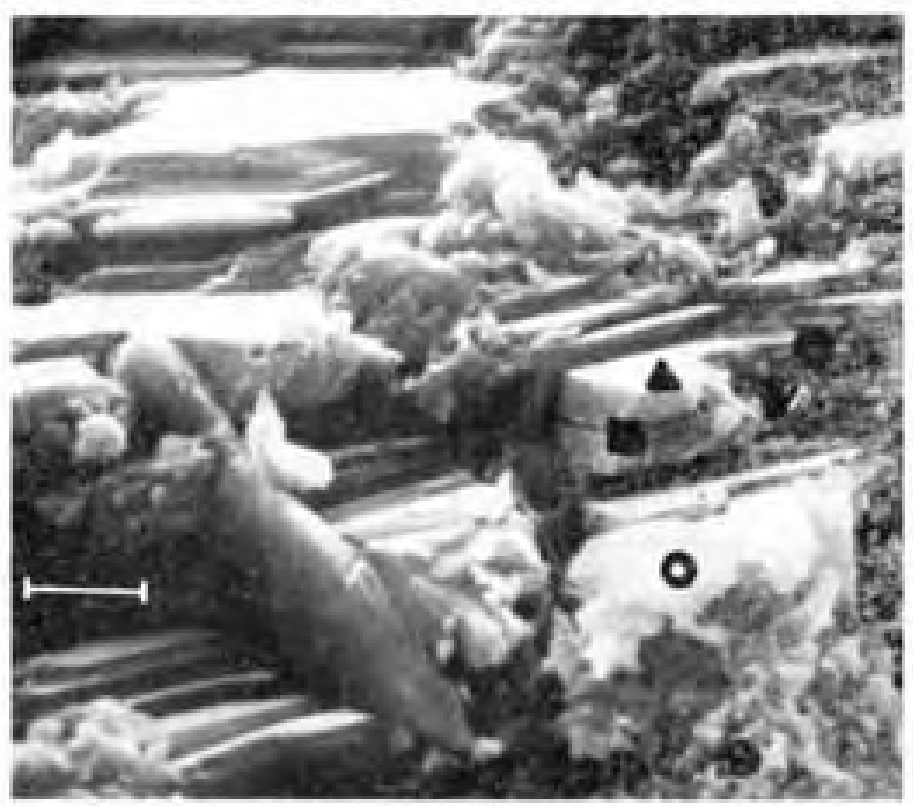

$$
\begin{aligned}
& \mathrm{CaO} / \mathrm{S} \mathrm{n}_{2} \\
& \text { - 8. } 7 . \\
& \text { A 8. } \quad 3.6 \\
& \text { จ 11. } 04.2
\end{aligned}
$$

FIG. 12

Growth of calcium hydroxide crystals through calc1um silicate hydrate gel. W:C 0.6, hydrated 318 days at $24^{\circ} \mathrm{C}$. 


\section{LIST OF FIGURES}

F1gure 1. Schematic diagram of energy-d1spersive $x$-ray spectrometer.

Figure 2. Calibration for determination of $\mathrm{CaO} / \mathrm{S}_{2} \mathrm{O}_{2}$ ratio.

Figure 3. Calibration for determination of $\mathrm{CaO} / \mathrm{SO}_{3}$ ratio.

Figure 4. Calibration for determination of $\mathrm{CaO}_{\mathrm{O}} \mathrm{Al}_{2} \mathrm{O}_{3}$ ratio.

Figure 5. Spherulitic cluster of calcium silicate hydrate gel. $W: C 0.6$, hydrated 185 days at $40^{\circ} \mathrm{C}$.

Figure 6. Short-fibered clusters of calcium silfcate hydrate gel. W:C 0.6 , hydrated for 7 days at $6^{\circ} \mathrm{C}$.

Figure 7. Calclum hydroxide plates formed at early stage of hydration. W:C 0.6 hydrated 1 day at $24^{\circ} \mathrm{C}$.

Figure 8. Young calcium sllicate hydrate gel clusters. W:C 0.6, hydrated for 7 days at $6^{\circ} \mathrm{C}$.

F1gure 9. Massfve calcium hydroxide crystal. W:C 0.6, hydrated for 185 days at $40^{\circ} \mathrm{C}$.

Figure 10. Calcium hydroxide crystal growing through calcium silicate hydrate gel. $W: C 0.4$, hydrated for 1 year at $6^{\circ} \mathrm{C}$.

Figure 11. Intermingling of calcium hydroxide and calcium silfcate hydrate gel. W:C 0.4 , hydrated for 1 year at $6^{\circ} \mathrm{C}$.

Figure 12. Growth of calcium hydroxide crystals throuph calcium sillcate hvdrate gel. $W: C 0.6$, hydrated 318 days at $24^{\circ} \mathrm{C}$.

Figure 13. Remnant grain of $\mathrm{C}_{3} \mathrm{~S}$. W:C 0.6 , hydrated for 4 days at $6{ }^{\circ} \mathrm{C}$.

F1gure 14. Apparent remant grain of $B-C_{2} S$. W:C 0.6 , hydrated 185 days at $40^{\circ} \mathrm{C}$.

Figure 15. Region surrounding possible fragment of "1nner product" with apparent columnar zone above. W:C 0.6 , hvdrated 2 davs at $6{ }^{\circ} \mathrm{C}$.

F1gure 16. Higher magniflcation view of area out11ned in F1gure 15. 